九州大学学術情報リポジトリ

Kyushu University Institutional Repository

\title{
The Effect of Egg-White Lysozyme on the Growth of Cheese Starter Organisms. I
}

Akashi, Akira

Laboratory of Chemistry and Technology of Animal Products, Faculty of Agriculture, Kyushu University

https://doi.org/10.5109/22819

出版情報 : 九州大学大学院農学研究院紀要. 17 (1)，pp.67-73，1972-08. Kyushu University バージョン：

権利関係 : 


\title{
The Effect of Egg-White Lysozyme on the Growth of Cheese Starter Organisms. I
}

\author{
Akira Akashi \\ Laboratory of Chemistry and Technology of Animal Products, \\ Faculty of Agriculture, Kyushu University, Fukuoka
}

(Received December 5, 1971)

\begin{abstract}
The effect of egg-white lysozyme was examined for two Streptococcus cremoris strains which are used in cheese processing as a starter. In a low concentration of lysozyme such as in 0.000025 \% solution, these two strains were found to be activated to grow. The differences of 0 . D. at $560 \mathrm{~m} \mu$ between control and sample were increasing from 90 minutes after incubation at $30^{\circ} \mathrm{C}$, and the difference at 480 minutes after incubation was 0.07 in $\mathrm{AM}_{1}$ and was 0.09 in $\mathrm{HP}$. These results are significant because the increased acid by the activated Streptococcus cremoris would inhibit the contaminating organisms to some extent.
\end{abstract}

The lytic activity of egg-white lysozyme to gram-positive organisms has been reported by Thompson (1952) and other several workers. However, the effect of egg-white lysozyme used for the infant diet has been reported recently by Ferlazzo (1961), Rossi (1961), Buccellato (1961) and Sukegawa (1967). By them a growth factor of lysozyme to Lactobacillus bifidus has been reported.

Weiss and Rettger (1934) reported that Lactobacillus bifidus was similar in a bacteriological nature to $\mathbf{L}$. acidophilus. However, Lactobacilfus bijidus has been recognized as a different species by Hayward et al. (1955), Ochi and Mitsuoka (1968) because this strain is different from other Lactobacillus strains in the point of the cell-shape, the requirement of nutrition and the metabolism. OrlaJensen (1924) has suggested to rank this strain as Bifidobacterium.

Recently, Lactobaciffus bijidus has been utilized in a fermentative milk product or lactic acid drink in which lactic Streptococcus such as S. lactis and S. cremoris are used as a starter. To utilize lysozyme in milk products, its effect to lactic Streptococcus must be examined. In this paper, the effect of egg-white lysozyme on two starter organisms is reported.

\section{MATERIALS AND METHODS}

Organisms : Streptococcus cremoris. AM, (slow fermentative strain) and HP (fast fermentative strain) which are stock strains of Dairy Research Institute, Palmerston North, New Zealand.

Egg-white lysozyme (Sigma Company) : This enzyme dissolved in $0.1 \mathrm{M}$ phosphate buffer ( $\mathrm{pH}$ 6.8) to $0.1 \%$ concentration as stock solution was sterilized 
by the millipore filter (G. S., $0.22 \mu$, Bedford, Massachusetts U.S.A.)

Medium : $\mathrm{M}_{6}$ (lactose, $20 \mathrm{~g}$; ascorbic acid, $0.5 \mathrm{~g}$; sodium acetate $\cdot 3 \mathrm{H}_{2} \mathrm{O}, 2.8 \mathrm{~g}$ polypepton, $10 \mathrm{~g}$; beef extract, $5 \mathrm{~g}$; yeast extract, $2.5 \mathrm{~g}$; phyton, $5 \mathrm{~g}$; agar, $1 \mathrm{~g}$;) was used.

Assay method: Assay method which was carried out by the method reporter by Akashi (1965), is shown in Fig. 1.

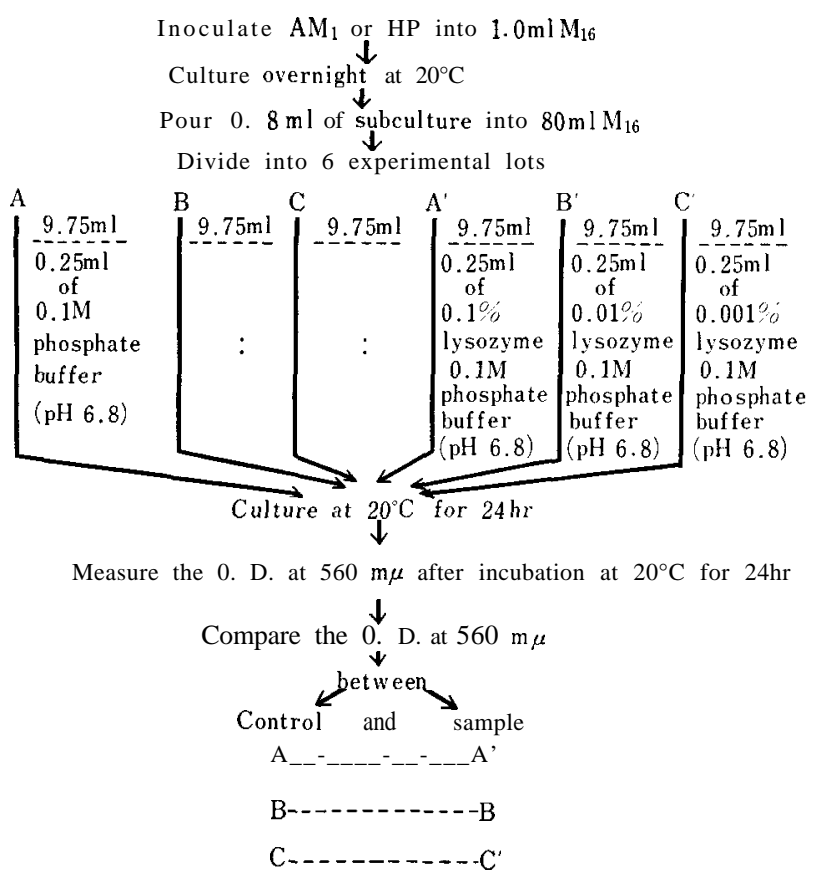

Fig. 1. Assay method carried out at $20^{\circ} \mathrm{C}$.

As shown in Fig. 1 the experiment was carried out in both strains. Subculture of each strain was poured into $M$, in the rate of one percent. 0 . D. at $560 \mathrm{~m} \mu$ of $\mathrm{A}, \mathrm{B}$ and $\mathrm{C}$ (without lysozyme) and $\mathrm{A}^{\prime}, \mathrm{B}^{\prime}$ and $\mathrm{C}^{\prime}$ (with lysozyme) were measured respectively. Control and sample (A and $\left.A^{\prime}\right),\left(B\right.$ and $\left.B^{\prime}\right),(C$ and $C^{\prime}$ ) were compared each other.

In control (A, B and $\mathrm{C}$ ), $0.25 \mathrm{ml}$ of $0.1 \mathrm{M}$ phosphate buffer ( $\mathrm{pH}$ 6.8) was added to $9.75 \mathrm{ml}$ of $\mathrm{M}_{16}$ containing subculture of Streptococcus cremoris (AM, and HP). In sample $A^{\prime}, 0.25 \mathrm{ml}$ of $0.1 \%$ lysozyme solution was added to $9.75 \mathrm{ml}$ of $\mathrm{M}_{16}$ containing subculture of AM, or HP strain, the final concentration of which turned out into $0.0025 \%$. In sample $\mathrm{B}^{\prime}, 0.25 \mathrm{ml}$ of $0.01 \%$ lysozyme was added to $9.75 \mathrm{ml}$ of $\mathrm{M}_{6}$ containing subculture of $\mathrm{AM}$, or $\mathrm{HP}$ strain, the final concentration of which turned out into to $0.00025 \%$.

The same procedure mentioned above was carried out by using $0.001 \%$ lyso. zyme solution in sample $C^{\prime}$, the final concentration of which became to 0.000025 
$\%$. After incubation at $20^{\circ} \mathrm{C}$, O.D. at $560 \mathrm{~m} \mu$ was measured in each solution respectively. The procedure shown in Fig. 1 was repeated in four experiments.

\section{RESULTS}

The mean values of 0 . D. at $560 \mathrm{~m} \mu$ in every experimental part after repeating the procedure shown in Fig. 1 are shown in Tables 1 and 2.

Table 1. The mean values of 0 . D. at $560 \mathrm{mp}$ in four experiments by using AM,.

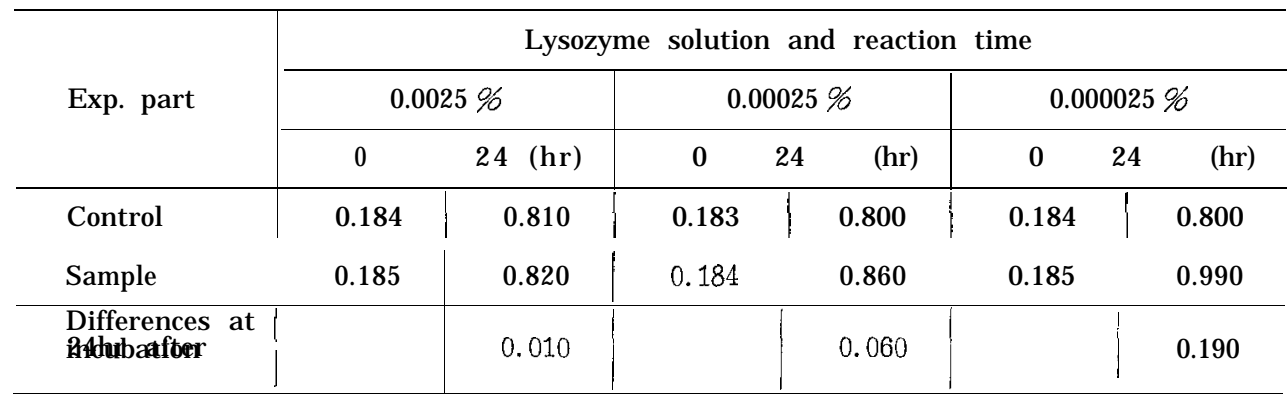

Table 2. The mean values of 0 . D. at $560 \mathrm{~m} \mu$ in four experiments by using HP.

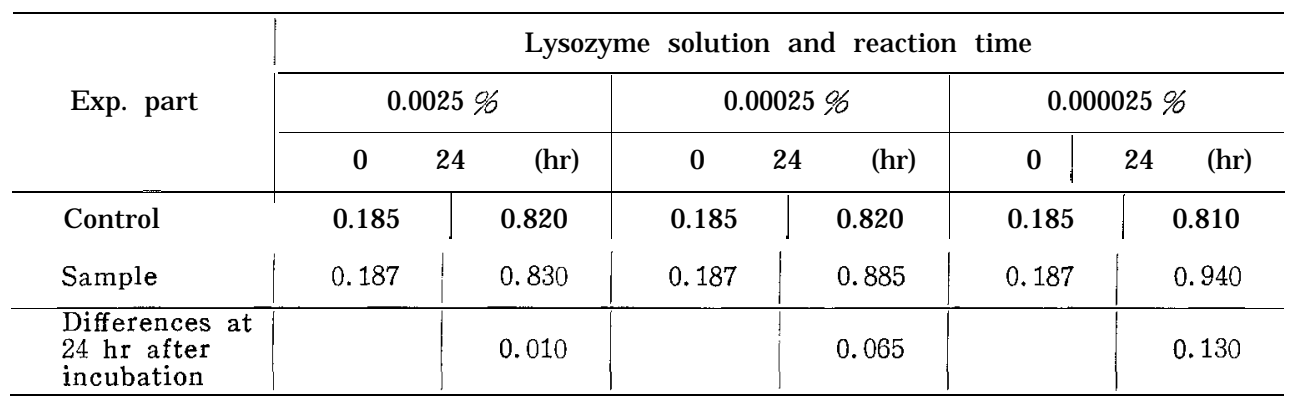

As shown in Tables 1 and 2, by using $0.0025 \%, 0.00025 \%$ and $0.000025 \%$ lysozyme solution, the highest difference of 0 . D. at $560 \mathrm{~m} \mu$ between control and sample after $24 \mathrm{hr}$ was observed in $0.000025 \%$ solution. These values decreased in the order of $0.000025 \%, 0.00025 \%$ and $0.0025 \%$ solution. Based upon these results, it might be presumed that lysozyme would activate the growth of Streptococcus cremoris in a low concentration such as $0.000025 \%$ solution.

The procedure carried out at $30^{\circ} \mathrm{C}$ is shown in Fig. 2. The adding lysozyme concentration used in this experiment was $0.000025 \%$, whereas in this concentration the largest difference of 0 . D. at $560 \mathrm{~m} \mu$ between control and sample was observed in the experiment carried out at $20^{\circ} \mathrm{C}$ for $24 \mathrm{hr}$ as shown in Tables 1 and 2 .

The procedure shown in Fig. 2 was repeated in four experiments. 0. D. at $560 \mathrm{~m} \mu$ on $0^{\prime}, 30^{\prime}, 60^{\prime}, 90^{\prime}, 120^{\prime}, 240^{\prime}, 300^{\prime}, 360^{\prime}, 420^{\prime}$, and $480^{\prime}$ after incubation at $30^{\circ} \mathrm{C}$ were measured respectively. The mean values of 0 . D. at $560 \mathrm{~m} \mu$ after four experiments are shown in Tables 3 and 4. The growth curves of AM, and HP 


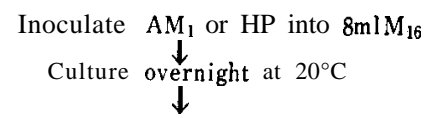

Pour $2 \mathrm{ml}$ of cultures into $200 \mathrm{ml} \mathrm{M}_{16}$ and mix gently

$\downarrow$

Divide into two parts
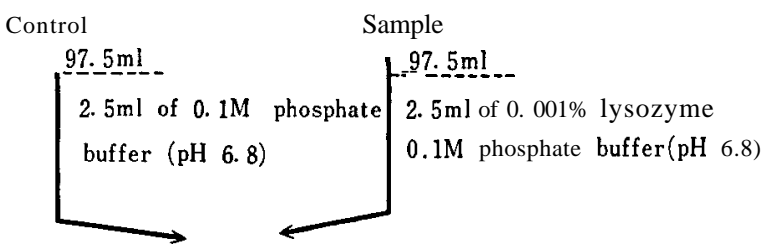

Divide $10 \mathrm{ml}$ of each sample into sterilized test tube respectively

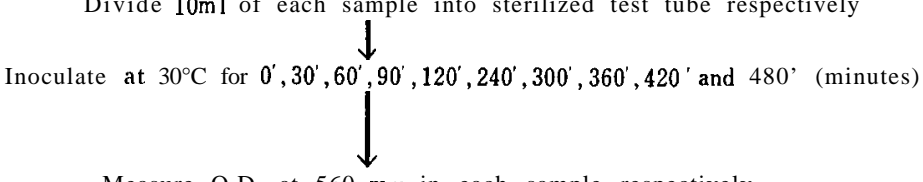

Measure O.D. at $560 \mathrm{~m} \mu$ in each sample respectively

Fig. 2. Assay method carried out at $30^{\circ} \mathrm{C}$.

Table 3. The growth rate of control (without lysozyme) and sample (with lysozyme) in $\quad \mathrm{AM}_{1}$.

(minutes)

\begin{tabular}{l|c|c|c|c|c|c|c|c|c|c}
\hline \multirow{2}{*}{\begin{tabular}{l} 
Exp. part \\
\cline { 2 - 7 }
\end{tabular}} & 0 & 30 & 60 & 90 & 120 & 240 & 300 & 360 & 420 & 480 \\
\hline $\begin{array}{l}\text { Control } \\
\text { Sample }\end{array}$ & 0.210 & 0.213 & 0.2201 & 0.230 & 0.290 & 0.3701 & 0.5001 & 0.503 & 0.504 & 0.510 \\
\hline $\begin{array}{l}\text { Difference at 480 minutes } \\
\text { after incubation }\end{array}$ & 0.210 & 0.213 & 0.2301 & 0.2401 & 0.310 & 0.410 & 0.560 & 0.5661 & 0.580 & 0.600 \\
\hline
\end{tabular}

Table 4. The growth rate of control (without lysozyme) and sample (with lysozyme) in HP.

(minutes)

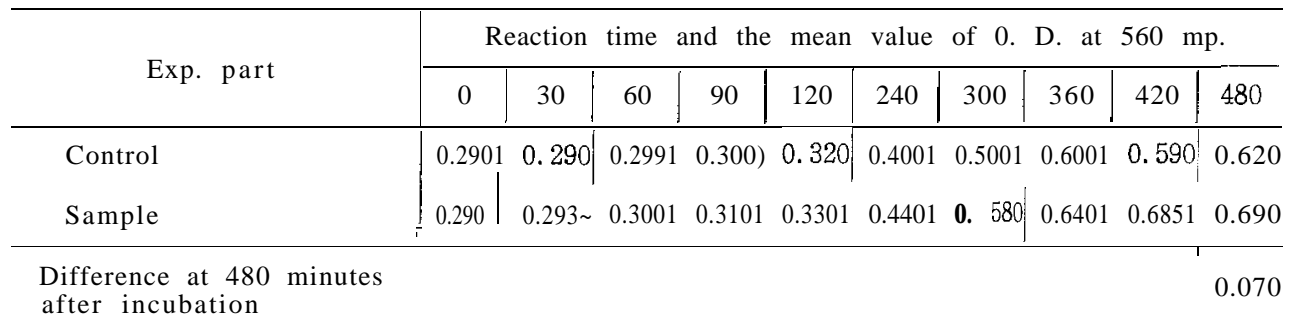




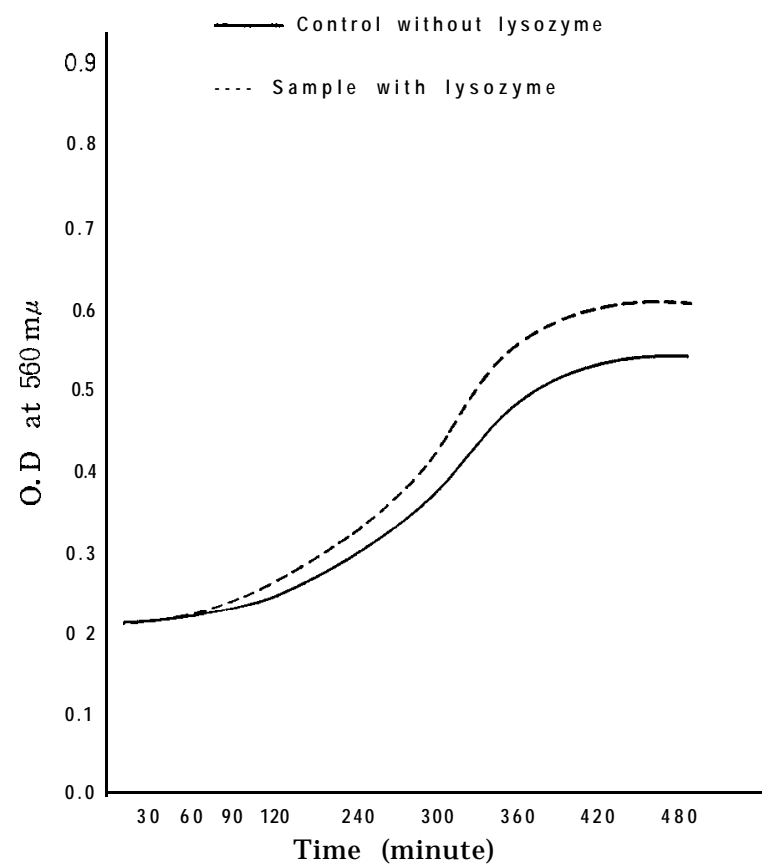

Fig. 3 The growth curve of $\mathrm{AM}_{1}$ strain cultured at $30^{\circ} \mathrm{C}$ for $\mathrm{O}-480$ minutes.

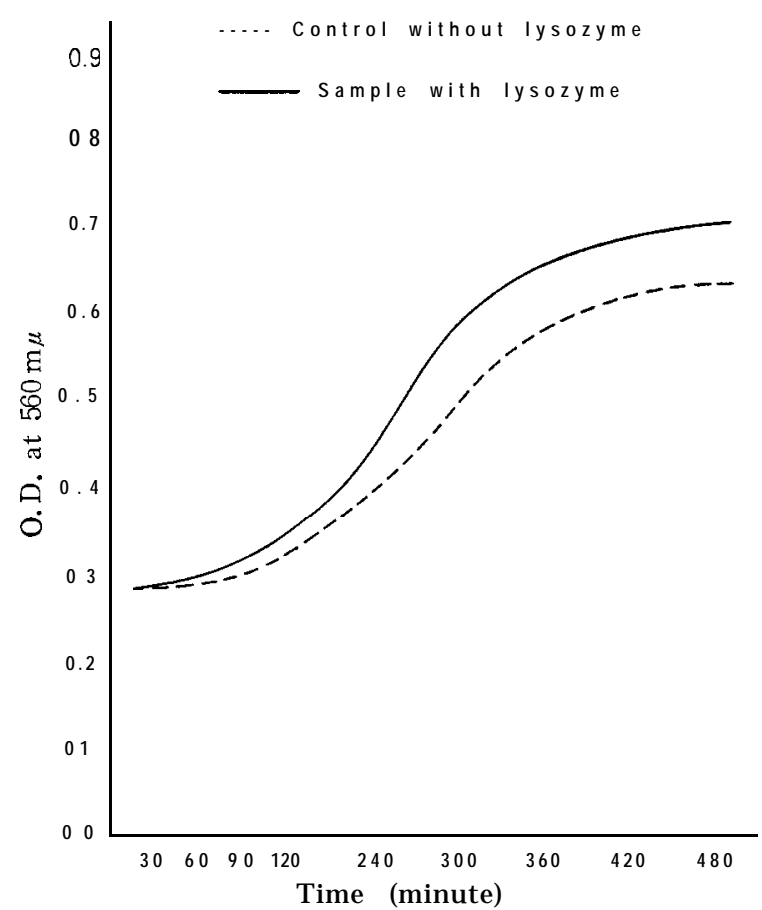

Fig. 4 The growth curve of $\mathrm{HP}$ strain cultured at $30^{\circ} \mathrm{C}$ for $\mathrm{O}-480$ minutes. 
strain are shown in Figs. 3 and 4.

As shown in Tables 3 and 4, the difference of 0 . D. at $560 \mathrm{~m} \mu$ between control (without lysozyme) and sample (with lysozyme) after incubation at $30^{\circ} \mathrm{C}$ for 480 minutes was 0.07 in HP strain and 0.09 in AM, strain. In each strain, 0. D. at $560 \mathrm{~m} \mu$ of sample at every reaction time was higher than that of control. Especially, these differences increased after 90 minutes. As shown in Figs. 3 and 4, $\mathrm{HP}$ strain reached to the stational phase faster than AM, strain.

\section{DISCUSSION}

It is well known that egg-white lysozyme lyses the gram-positive organisms, however, in this experiment, two strains of Streptococcus cremoris were activated to grow especially in $0.000025 \%$ lysozyme solution. By Ferlazzo, Rossi, Buceellato and Sukegawa, the growth factor of lysozyme to Lactobacillus bifidus was reported.

These results in Lactobacillus and the data of Streptococcus in this experiment might be caused by the different chemical constitutions of their cell walls comparing with those of other organisms which are lysed by lysozyme.

By Ochoa (1958) and Brien (1960), the cell wall of Lactobacillus was reported as a mutant cell wall which lacks acetyl-glucosamine containing oligosaccharide. By Brockaman (1954) a-lipoic acid was reported as a growth factor for lactic Streptococcus. Whether $\alpha$-lipoic acid would be increased in a lactate medium by adding lysozyme would be examined in another experiment, and another mechanism in activating the growth of Streptococcus cremoris would be also confirmed afterwards. To confirm egg-white lpsozyme as a growth factor to Streptococcus cremoris, further experiment on the viable bacterial count in the growth of these strians would be needed.

However, though the differences of 0 . D. at $560 \mathrm{~m} \mu$ between control (without lysozyme) and sample (with lysozyme) were 0.07-o. 09 in two strains after incubation at $30^{\circ} \mathrm{C}$ for 480 minutes, these results might be significant because the contaminating organisms would be inhibited by the increased acid produced by the activated Streptococcus cremoris to some extent.

\section{ACKNOWLEDGEMENT}

The author is grateful to Dr. R. C. Lawrence and Dr. L. E. Pearce, Department of Biochemistry and Microbiology, Dairy Research Institute, Palmerston North, New Zealand for their valuable suggestions and for their kindness in providing facilities available for this study, and the author is also grateful to Dr. Lawrence for reading the manuscript of this paper.

\section{REFERENCES}

Akira A. (1965) : The 1ytic action of egg-white lysozyme on the food contaminating microorganisms. J. Food Hyg. Soc. Japan, 6 (6), 543.

Brien P. J. 0. et al, (1960) : The morphological changes of Lactobacillus bifidus var. 
pennsylvanicus produced by a cell-wall precursor. Biochim. et Biophys. Acta, 37, 361.

Brockaman J. A. et al. (1954): Proposed structure for protogen-A and protogen-B. J. A m.

Chem. Soc., 76, 1827.

Bucellato G. (1961): Atti II Symp. Intern. Lisozima, 7.

Ferlazzo A. and Lombard G. (1961): ibid.

Hayward A. C., Hale C. M. F. and Bisset K. A. (1955): The morphology and relationship of Lactobacillus bijidus. J. Gen. Microbiol., 13, 292.

Ochi Y. and Mitsuoka T. (1968) : Lactobacillus bijidus taxonomy. Japanese J. Vet. Sci., 20, 71.

Ochoa 0. (1958) : Recent progress in microbiology, p. 122, Almquist and Wilksells, Uppsala, Sweden.

Orla-Jensen S. (1924): The lactic acid bacteria. J. Bact., 30, 1935.

Rossi R. (1961) : Atti II Symp. Intern. Lisozima, 7.

Sukegawa G. (1967) : The growth factor effect of egg-white lysozyme to Lactobacillus bifidus. J. Jap. Soc. Food and Nutrition, 29, 45.

Thompson A. R. (1952): The C-terminal residue of lysozyme. Nature, 169, 495.

Weiss J. E. and Rettger L. F. (1934): Lactobacillus bifidus. J. Bact., 28, 501. 